\title{
Palaeoproterozoic mafic and intermediate metavolcanic rocks in the Turku area, SW Finland
}

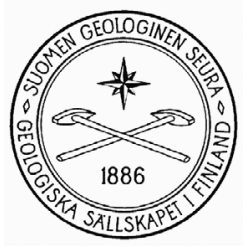

\author{
MARKKu VäISÄNEN ${ }^{1) *}$ AND GUSTAV WesterLUND ${ }^{2)}$ \\ ${ }^{1)}$ Department of Geology, FI-20014 University of Turku, Finland \\ ${ }^{2)}$ Department of Geology and Mineralogy, Abo Akademi University, FI-20500 Turku, Finland
}

\begin{abstract}
Twenty two samples were analysed from mafic and intermediate volcanic rocks from the Turku area along $\sim 60 \mathrm{~km}$ long north-south geotraverse. Geographically and lithologically the samples were divided into the Pargas, Turku and Vahto groups. The Pargas and Turku groups consist of mafic units and intercalations within migmatitic gneisses. Their geochemical compositions are very similar. In average, they show quite flat REE curves and the multielement diagrams show moderate LILE enrichments, minor negative Ta-Nb anomalies and straight HFSE curves. We infer these as transitional between MORB and VAB. The Vahto group consists of thicker volcanic sequences in connection with synorogenic plutonic rocks. The data show enriched LREEs, LILEs, Th and P combined with negative Ta-Nb anomalies, i.e. the Vahto group shows subduction component. We interpret that the Vahto volcanic rocks belong to the Häme belt. The geochemical data indicate that the Pargas and Turku groups were formed in extensional, possibly back-arc or intra-arc setting while the Vahto group was formed at continental volcanic arc.
\end{abstract}

Key words: metavolcanic rocks, geochemistry, trace elements, tectonics, back-arc basins, volcanic arcs, Paleoproterozoic, Svecofennian, Parainen, Turku, Vahto, Finland

*Corresponding author email: markku.vaisanen@utu.fi

\section{Introduction}

Geochemical modelling has become one of the most important tools in reconstructing the tectonic settings of ancient volcanic formations. The development of analytical techniques, ICP-MS method in particular, has increased the use of trace element modelling (e.g. Pearce, 1996; Macdonald et al., 2000) in research of Palaeoproterozoic igneous rocks.

Recently, Kähkönen (2005) reviewed the present state of knowledge regarding the Svecofennian supracrustal rocks in Finland. From that review it is apparent that there still are very few volcanic areas that are well-studied with modern geochemical methods. Evidently, for the orogen-scale modelling, data from new areas with analyses made by the most recent methods are most welcome.

In this contribution we present new geochemical data on Palaeproterozoic mafic and intermediate volcanic rocks from the Turku area, southwestern Finland. The purpose is to add new modern analyses to geochemical databases of volcanic rocks in Finland and interpret tectonic setting of the studied volcanic units. 


\section{Geological setting}

The main volcanic belts in southern Finland are called the Uusimaa belt and the Häme belt. The volcanism in the belts took place both in volcanic arc and in extensional settings (Lindroos \& Ehlers, 1994; Väisänen \& Mänttäri, 2002; Kähkönen, 2005; Lahtinen et al., 2005). The age of volcanism is dated at 1.90 - 188 Ga (Vaasjoki, 1995; Reinikainen, 2001; Väisänen \& Mänttäri, 2002; Ehlers et al., 2004; Skyttä et al., 2005). The belts are separated and surrounded by sedimentary migmatitic mica gneisses and plutonic rocks of varying ages. Late Svecofennian $1.85-1.81$ Ga granites (e.g. Nironen, 2005, and references therein) are common as well as Mesoproterozoic 1.65 - 1.54 Ga rapakivi granites (e.g. Rämö $\&$ Haapala, 2005, and references therein). These rock types are typical to southern Svecofennia, contrary to central Svecofennia (terms after Kähkönen, 2005), where the younger granites are absent. Accordingly, these areas are interpreted as separate terranes (Lahtinen, 1996; Rämö et al., 2001; Fig. 1a).

Our study profile covers volcanic rocks in the Vahto area that apparently in the north is the western extension of the Häme belt. The middle and NW part of the profile (Turku) consisting mainly of migmatitic mica gneisses cannot be straightforwardly connected to either of the main belts (Fig 1a). Lithology in the southern part (Pargas) containing marbles connects it to the Uusimaa belt. All rocks are deformed and metamorphosed in high temperature $\left(700-800{ }^{\circ} \mathrm{C}\right)$ and low pressure ( $4-6 \mathrm{kbars})$ conditions and even the mafic volcanic rocks are partly migmatised (van Duin, 1992; Ehlers et al., 1993; Väisänen \& Hölttä, 1999).

\section{Sampled lithology}

Our data were collected from a $\sim 60 \mathrm{~km}$ long northsouth traverse. The samples are divided into three main geographical and lithological groups: the Pargas, Turku and Vahto groups. The sample locations are shown in Fig. 1 b.

The mafic rock samples from the Pargas group come from the oval-shaped Pargas synform that forms a doubly plunging basin structure (Lindberg et al., 1994). The mafic volcanic horizon is $\sim 500 \mathrm{~m}$ thick in average and is overlain by marbles and mica gneisses. Primary structures were not found.

The Turku group consists of mafic volcanic intercalations within the migmatitic mica gneisses in the central and northwestern part of the study area. Intercalations are mainly narrow, ranging from a few tens of centimetres to a few tens of metres. In the southern part of the Turku group the rocks form several hundred metres thick sequences and pillow structures are encountered locally (Lindberg et al., 1994; 118MAV-02 in Fig. 1). Marbles are not found to be associated with them.

The Vahto group is located on both southern and northern side of, and partly within, the large synorogenic tonalite-quartzdiorite-granodiorite $1.87 \mathrm{Ga}$ intrusion (van Duin, 1992; Nironen, 1999; Väisänen et al., 2002; Väisänen, 2007). The mafic-intermediate volcanic rocks form up to two kilometres thick sequences which are in places intercalated with sedimentary rocks. Volcanic breccias were locally found (Westerlund, 2005). Felsic rocks also exist, but they were excluded from this study. The geochemical data on volcanic rocks in Van Duin (1992) come from the same area. Therefore, they are shown for comparison.

\section{Analytical procedures}

Twenty two samples on mafic and intermediate metavolcanic rocks were analysed for major and trace elements (Table 1). Fourteen samples were analysed at Acme Analytical Laboratories Ltd. (Acme) in Vancouver, Canada. Major elements and $\mathrm{Cr}, \mathrm{Ni}$ and $\mathrm{Sc}$ were analysed by inductively coupled plasma emission (ICP). The other trace elements were analysed by inductively coupled plasma-mass spectrometry (ICPMS). Eight samples were analysed at Geological Survey of Finland (GTK) where major elements and As, $\mathrm{Ba}, \mathrm{Bi}, \mathrm{Cr}, \mathrm{Cu}, \mathrm{Ga}, \mathrm{Mo}, \mathrm{Ni}, \mathrm{Pb}, \mathrm{Rb}, \mathrm{S}, \mathrm{Sb}, \mathrm{Sn}, \mathrm{Sr}$, $\mathrm{V}, \mathrm{Zn}$, and $\mathrm{Zr}$ were analysed by $\mathrm{X}$-ray fluorescence (XRF). The other trace elements were analysed by ICP-MS. 


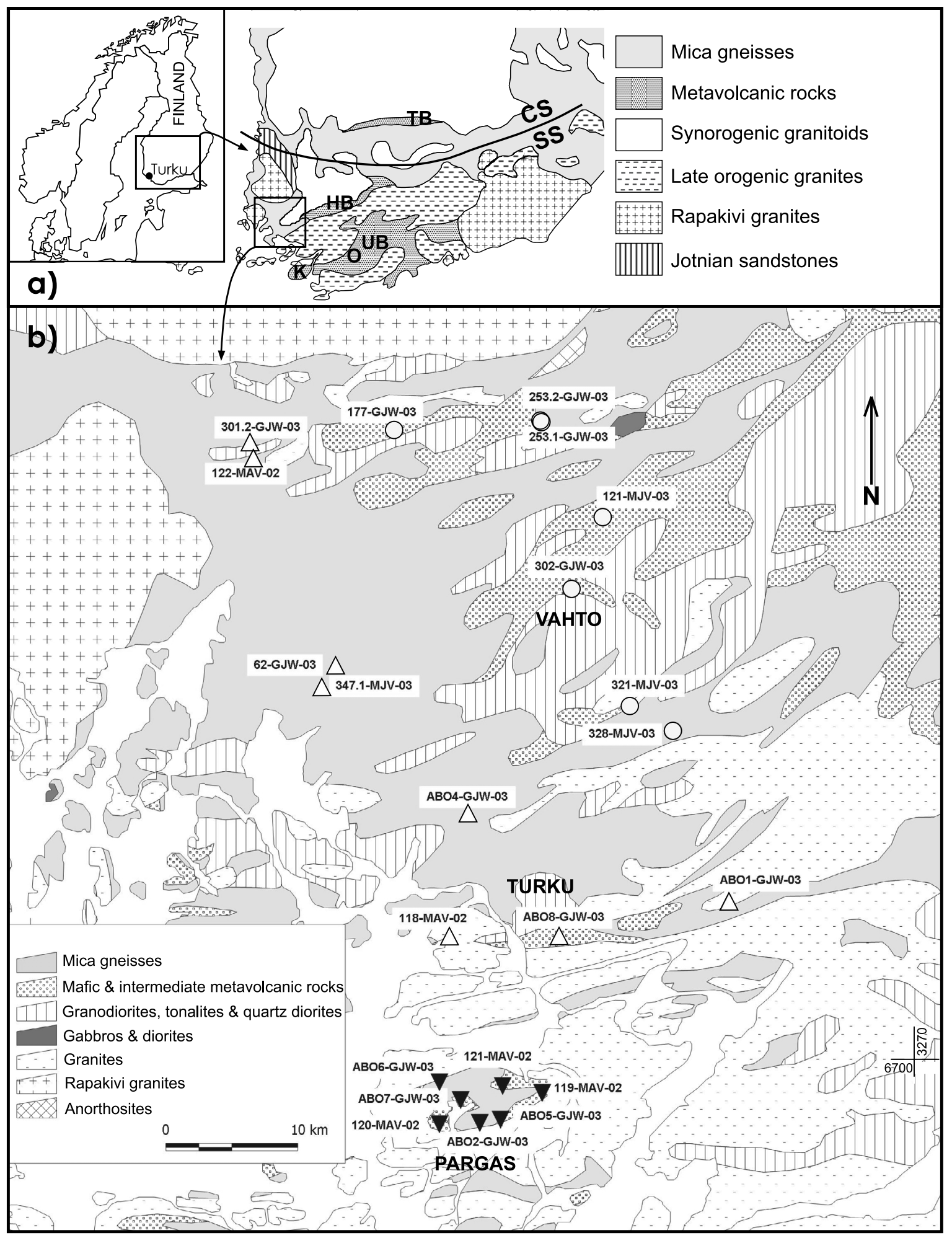

Fig. I. a) Main lithological units in southern Finland. CS = central Svecofennia; SS= southern Svecofennia; TB = Tampere belt; $\mathrm{HB}=$ Häme belt; UB = Uusimaa belt. b) Geological map of southwestern Finland, modified after Korsman et al. (1997). Sample localities are marked with same symbols as samples in Fig. 2. 
Table I. Chemical whole rock analyses of volcanic rocks from the Turku area (oxides and $\mathrm{S}$ in w\%, other elements in ppm).

\begin{tabular}{|c|c|c|c|c|c|c|c|c|c|c|c|}
\hline Sample & $\begin{array}{l}\text { ABO2- } \\
\text { GJW-03 }\end{array}$ & $\begin{array}{l}\text { ABO5- } \\
\text { GJW-04 }\end{array}$ & $\begin{array}{l}\text { ABO6- } \\
\text { GJW-04 }\end{array}$ & $\begin{array}{l}\text { ABO7- } \\
\text { GJW-04 }\end{array}$ & $\begin{array}{c}\text { 119- } \\
\text { MAV-02 }\end{array}$ & $\begin{array}{c}120- \\
\text { MAV-02 }\end{array}$ & $\begin{array}{c}121- \\
\text { MAV-02 }\end{array}$ & $\begin{array}{c}301.2- \\
\text { GJW-03 }\end{array}$ & $\begin{array}{c}\text { ABO1- } \\
\text { GJW-03 }\end{array}$ & $\begin{array}{l}\text { ABO8- } \\
\text { GJW-04 }\end{array}$ & $\begin{array}{l}\text { ABO4- } \\
\text { GJW-03 }\end{array}$ \\
\hline Group & Pargas & Pargas & Pargas & Pargas & Pargas & Pargas & Pargas & Turku & Turku & Turku & Turku \\
\hline Laboratory & Acme & Acme & Acme & Acme & Acme & Acme & Acme & GTK & Acme & Acme & Acme \\
\hline $\mathrm{SiO}_{2}$ & 49.13 & 50.83 & 49.64 & 49.40 & 47.12 & 49.72 & 49.74 & 48.50 & 45.79 & 53.24 & 47.22 \\
\hline $\mathrm{TiO}_{2}$ & 0.71 & 1.21 & 0.79 & 0.88 & 0.71 & 1.24 & 0.91 & 0.92 & 0.68 & 0.82 & 1.15 \\
\hline $\mathrm{Al}_{2} \mathrm{O}_{3}$ & 14.48 & 14.84 & 14.77 & 16.87 & 17.39 & 14.38 & 14.75 & 12.20 & 13.69 & 18.19 & 14.84 \\
\hline $\mathrm{FeO}$ & & & & & & & & 11.60 & & & \\
\hline $\mathrm{Fe}_{2} \mathrm{O}_{3}$ & 11.25 & 8.75 & 10.85 & 11.32 & 10.82 & 13.17 & 11.70 & & 14.04 & 11.12 & 12.66 \\
\hline $\mathrm{MnO}$ & 0.20 & 0.18 & 0.16 & 0.12 & 0.14 & 0.14 & 0.17 & 0.20 & 0.19 & 0.14 & 0.16 \\
\hline $\mathrm{MgO}$ & 7.68 & 4.75 & 7.48 & 6.44 & 7.46 & 5.93 & 6.90 & 10.70 & 13.64 & 4.60 & 9.02 \\
\hline $\mathrm{CaO}$ & 11.96 & 15.66 & 12.85 & 11.14 & 12.25 & 12.34 & 12.38 & 10.78 & 9.16 & 8.89 & 11.52 \\
\hline $\mathrm{Na}_{2} \mathrm{O}$ & 2.55 & 2.34 & 2.26 & 2.82 & 1.95 & 2.61 & 2.55 & 0.90 & 1.47 & 1.57 & 1.70 \\
\hline $\mathrm{K}_{2} \mathrm{O}$ & 0.97 & 0.61 & 0.47 & 0.36 & 0.77 & 0.14 & 0.16 & 0.49 & 0.25 & 0.81 & 0.65 \\
\hline $\mathrm{P}_{2} \mathrm{O}_{5}$ & 0.05 & 0.12 & 0.08 & 0.08 & 0.04 & 0.09 & 0.07 & 0.12 & 0.08 & 0.11 & 0.14 \\
\hline S & 0.02 & 0.01 & 0.1 & 0.01 & 0.04 & 0.14 & 0.01 & 0.004 & 0.04 & 0.01 & 0.01 \\
\hline Total & 99.00 & 99.30 & 99.45 & 99.44 & 98.69 & 99.90 & 99.34 & 96.42 & 99.03 & 99.50 & 99.07 \\
\hline $\mathrm{Cr}$ & 68.4 & 34.2 & 218.9 & 136.8 & 246.3 & 13.7 & 205.3 & 841 & 41.1 & 54.7 & 335.3 \\
\hline $\mathrm{Ni}$ & 11.4 & 20 & 58 & 27 & 19.6 & 6.5 & 13.5 & 92 & 42.6 & 20 & 19.6 \\
\hline V & 243 & 301 & 272 & 268 & 210 & 328 & 269 & 284 & 161 & 217 & 248 \\
\hline $\mathrm{Zn}$ & 24 & 20 & 17 & 12 & 24 & 22 & 13 & 138 & 18 & 31 & 21 \\
\hline $\mathrm{Cu}$ & 116.5 & 6.4 & 70.3 & 6.7 & 362.1 & 98.6 & 39.4 & $<20$ & 133.2 & 2.3 & 14 \\
\hline As & 66.2 & 2 & 2.9 & 3.4 & 0.9 & 0.5 & 1.7 & $<30$ & 14.7 & 9.9 & 1.9 \\
\hline $\mathrm{Ga}$ & 14.6 & 18.2 & 16.9 & 17.9 & 16.6 & 17.7 & 16 & 20 & 14.4 & 21 & 16.8 \\
\hline $\mathrm{Rb}$ & 107.4 & 49.6 & 8.6 & 26.3 & 29.8 & 2.4 & 9.5 & 12.6 & 6.7 & 82.9 & 12 \\
\hline $\mathrm{Sr}$ & 190.9 & 342.5 & 142.6 & 156.4 & 177.2 & 156.4 & 159.7 & 197 & 135.1 & 216.1 & 244.1 \\
\hline $\mathrm{Ba}$ & 95 & 471.4 & 51.3 & 72 & 65 & 29 & 33 & 50 & 42 & 270.2 & 74 \\
\hline $\mathrm{Nb}$ & 1.5 & 4.5 & 2.8 & 1.6 & 1.2 & 2.6 & 1.8 & 2.98 & 2 & 6 & 5 \\
\hline $\mathrm{Ta}$ & $<.1$ & 0.3 & 0.2 & 0.1 & 0.3 & 0.1 & 0.1 & 0.2 & $<.1$ & 0.4 & 0.2 \\
\hline $\mathrm{Y}$ & 16.3 & 36.1 & 25 & 25.2 & 17.2 & 32 & 25.1 & 16.9 & 16.6 & 25.7 & 26.7 \\
\hline $\mathrm{Zr}$ & 37.8 & 102.6 & 44.5 & 54.8 & 33.8 & 52.5 & 43.5 & 48.5 & 40.1 & 72.2 & 65.9 \\
\hline $\mathrm{Hf}$ & 1 & 3.1 & 1.2 & 1.8 & 0.9 & 1.4 & 1.4 & 1.32 & 1.5 & 2.2 & 2 \\
\hline $\mathrm{U}$ & 0.3 & 1.6 & 0.2 & 0.5 & $<.1$ & $<.1$ & $<.1$ & 0.55 & 0.2 & 1.2 & 0.4 \\
\hline Th & 0.9 & 3 & 0.5 & 1.2 & 0.1 & $<.1$ & 0.2 & 0.6 & 0.4 & 2.9 & 0.6 \\
\hline $\mathrm{Pb}$ & 4.7 & 3.3 & 2.9 & 6.6 & 3 & 0.4 & 0.6 & $<30$ & 2.5 & 4.4 & 3.9 \\
\hline Sn & 26 & 12 & 3 & 13 & 5 & 2 & 8 & $<20$ & $<1$ & 5 & 1 \\
\hline $\mathrm{Sc}$ & 52 & 40 & 46 & 44 & 44 & 50 & 55 & 37.7 & 27 & 35 & 39 \\
\hline $\mathrm{La}$ & 3.2 & 8.9 & 5.4 & 4.1 & 2.1 & 4.5 & 3.4 & 4.77 & 3.9 & 12.6 & 7.4 \\
\hline $\mathrm{Ce}$ & 8.3 & 22.9 & 13.2 & 9.7 & 5.2 & 12.5 & 9.2 & 11.4 & 10.3 & 27 & 20.7 \\
\hline $\operatorname{Pr}$ & 1.11 & 3.31 & 1.86 & 1.4 & 0.79 & 1.83 & 1.39 & 1.52 & 1.24 & 3.34 & 2.78 \\
\hline $\mathrm{Nd}$ & 5.7 & 14.7 & 8.7 & 7.4 & 3.7 & 9.1 & 7 & 7.89 & 5.6 & 12.5 & 12.5 \\
\hline $\mathrm{Sm}$ & 1.7 & 4.1 & 2.6 & 2.4 & 1.5 & 2.8 & 2.2 & 2.2 & 1.7 & 3.1 & 3.5 \\
\hline $\mathrm{Eu}$ & 0.73 & 1.06 & 0.87 & 1.01 & 0.72 & 1.11 & 0.75 & 0.74 & 0.64 & 0.86 & 1.14 \\
\hline $\mathrm{Gd}$ & 2.14 & 5 & 3.44 & 3.17 & 1.9 & 3.87 & 3.03 & 2.89 & 2 & 3.42 & 3.5 \\
\hline $\mathrm{Tb}$ & 0.43 & 0.9 & 0.63 & 0.64 & 0.44 & 0.86 & 0.63 & 0.45 & 0.45 & 0.63 & 0.72 \\
\hline Dy & 2.78 & 5.39 & 3.91 & 4.03 & 3.09 & 5.24 & 4.34 & 3.1 & 2.77 & 3.86 & 4.6 \\
\hline Ho & 0.54 & 1.28 & 0.88 & 0.87 & 0.65 & 1.09 & 0.9 & 0.63 & 0.54 & 0.9 & 0.86 \\
\hline $\mathrm{Er}$ & 1.68 & 3.54 & 2.72 & 2.41 & 1.71 & 3.12 & 2.5 & 1.66 & 1.72 & 2.48 & 2.56 \\
\hline $\mathrm{Tm}$ & 0.23 & 0.53 & 0.36 & 0.38 & 0.26 & 0.48 & 0.38 & 0.25 & 0.24 & 0.37 & 0.37 \\
\hline $\mathrm{Yb}$ & 1.53 & 3.78 & 2.84 & 2.47 & 1.7 & 3.28 & 2.66 & 1.76 & 1.55 & 2.87 & 2.42 \\
\hline $\mathrm{Lu}$ & 0.26 & 0.51 & 0.35 & 0.34 & 0.28 & 0.48 & 0.4 & 0.23 & 0.27 & 0.37 & 0.4 \\
\hline
\end{tabular}

$<$ value below the given detection limit 
Table I. cont. Chemical whole rock analyses of volcanic rocks from the Turku area (oxides and S in w\%, other elements in Ppm).

\begin{tabular}{|c|c|c|c|c|c|c|c|c|c|c|c|}
\hline Sample & $\begin{array}{c}\text { 62- } \\
\text { GJW-03 }\end{array}$ & $\begin{array}{c}118- \\
\text { MAV-02 }\end{array}$ & $\begin{array}{c}122- \\
\text { MAV-02 }\end{array}$ & $\begin{array}{c}347.1- \\
\text { MJV-03 }\end{array}$ & $\begin{array}{c}\text { 177-GJW- } \\
03\end{array}$ & $\begin{array}{c}253.1- \\
\text { GJW-03 }\end{array}$ & $\begin{array}{c}253.2- \\
\text { GJW-03 }\end{array}$ & $\begin{array}{c}302- \\
\text { GJW-03 }\end{array}$ & $\begin{array}{c}\text { 121- } \\
\text { MJV-03 }\end{array}$ & $\begin{array}{c}321- \\
\text { MJV-03 }\end{array}$ & $\begin{array}{c}328- \\
\text { MJV-03 }\end{array}$ \\
\hline Group & Turku & Turku & Turku & Turku & Vahto & Vahto & Vahto & Vahto & Vahto & Vahto & Vahto \\
\hline Laboratory & Acme & Acme & Acme & Acme & GTK & GTK & GTK & GTK & GTK & GTK & GTK \\
\hline $\mathrm{SiO}_{2}$ & 48.19 & 48.48 & 52.26 & 48.50 & 50.80 & 52.00 & 51.40 & 54.20 & 48.20 & 51.40 & 57.70 \\
\hline $\mathrm{TiO}_{2}$ & 0.83 & 0.74 & 1.45 & 1.36 & 1.43 & 1.05 & 1.18 & 1.05 & 0.81 & 0.97 & 0.96 \\
\hline $\mathrm{Al}_{2} \mathrm{O}_{3}$ & 16.63 & 16.30 & 14.81 & 13.75 & 17.00 & 15.70 & 16.70 & 16.00 & 12.00 & 14.60 & 17.10 \\
\hline $\mathrm{FeO}$ & & & & & 9.67 & 10.35 & 7.66 & 8.79 & 10.45 & 9.16 & 8.35 \\
\hline $\mathrm{Fe}_{2} \mathrm{O}_{3}$ & 13.18 & 10.19 & 10.08 & 17.77 & & & & & & & \\
\hline $\mathrm{MnO}$ & 0.17 & 0.15 & 0.09 & 0.22 & 0.18 & 0.36 & 0.11 & 0.16 & 0.16 & 0.16 & 0.17 \\
\hline $\mathrm{MgO}$ & 8.04 & 8.59 & 7.15 & 6.52 & 6.50 & 6.53 & 5.66 & 5.80 & 11.40 & 7.53 & 2.68 \\
\hline $\mathrm{CaO}$ & 9.29 & 12.77 & 10.03 & 10.42 & 7.53 & 8.16 & 10.02 & 7.41 & 9.99 & 10.62 & 5.78 \\
\hline $\mathrm{Na}_{2} \mathrm{O}$ & 2.64 & 1.99 & 2.71 & 1.59 & 4.07 & 3.10 & 4.03 & 2.99 & 2.43 & 2.07 & 4.25 \\
\hline $\mathrm{K}_{2} \mathrm{O}$ & 0.38 & 0.18 & 0.47 & 0.19 & 1.07 & 1.09 & 0.75 & 1.73 & 0.38 & 0.50 & 1.52 \\
\hline $\mathrm{P}_{2} \mathrm{O}_{5}$ & 0.09 & 0.07 & 0.13 & 0.15 & 0.25 & 0.17 & 0.29 & 0.21 & 0.15 & 0.19 & 0.19 \\
\hline S & 0.01 & 0.02 & 0.04 & 0.04 & 0.009 & 0.006 & $<0.006$ & $<0.006$ & $<0.006$ & $<0.006$ & 0.011 \\
\hline Total & 99.45 & 99.48 & 99.22 & 100.51 & 98.52 & 98.52 & 97.81 & 98.32 & 95.97 & 97.20 & 98.71 \\
\hline $\mathrm{Cr}$ & 88.9 & 273.7 & 88.9 & 41.1 & 87 & 162 & 201 & 82 & 740 & 286 & 30 \\
\hline $\mathrm{Ni}$ & 43 & 33.5 & 29 & 11.4 & 55 & 93 & 82 & 40 & 166 & 80 & 20 \\
\hline V & 161 & 200 & 324 & 341 & 301 & 198 & 257 & 235 & 226 & 254 & 166 \\
\hline $\mathrm{Zn}$ & 38 & 14 & 26 & 18 & 88 & 134 & 68 & 117 & 91 & 90 & 123 \\
\hline $\mathrm{Cu}$ & 52.4 & 30.4 & 34.8 & 24.6 & 62 & 401 & $<20$ & 62 & 75 & 142 & 41 \\
\hline As & 4.1 & 1.9 & 12.9 & $<.5$ & $<30$ & $<30$ & $<30$ & $<30$ & $<30$ & $<30$ & $<30$ \\
\hline $\mathrm{Ga}$ & 18 & 13.4 & 18.1 & 17.5 & 22 & 25 & 24 & 26 & $<20$ & 27 & 28 \\
\hline $\mathrm{Rb}$ & 11.3 & 4.1 & 8.8 & 2.6 & 38.5 & 24.7 & 8.35 & 102 & 5.17 & 11.9 & 37.9 \\
\hline $\mathrm{Sr}$ & 314.8 & 189.9 & 193.6 & 185 & 582 & 381 & 727 & 478 & 531 & 380 & 425 \\
\hline $\mathrm{Ba}$ & 81 & 37 & 76 & 22 & 165 & 424 & 179 & 455 & 148 & 173 & 391 \\
\hline $\mathrm{Nb}$ & 3.3 & 1.4 & 4.6 & 5.5 & 4.94 & 5.65 & 7.94 & 5.5 & 3.19 & 4.45 & 7.09 \\
\hline $\mathrm{Ta}$ & 0.2 & $<.1$ & 0.3 & 0.3 & 0.32 & 0.31 & 0.61 & 0.36 & 0.21 & 0.31 & 0.48 \\
\hline Y & 23.9 & 19.4 & 23.4 & 38.1 & 24.3 & 17.5 & 19.6 & 17.2 & 14.3 & 14.4 & 27 \\
\hline $\mathrm{Zr}$ & 52.4 & 38.7 & 76.9 & 68.4 & 113 & 80.4 & 90.5 & 103 & 51.6 & 72.2 & 125 \\
\hline Hf & 1.5 & 1.1 & 2.4 & 2 & 2.86 & 2.09 & 2.07 & 2.58 & 1.22 & 2.09 & 3.14 \\
\hline $\mathrm{U}$ & 0.7 & 0.1 & 2 & 0.1 & 1.14 & 0.28 & 1.12 & 1.08 & 0.28 & 1.24 & 0.64 \\
\hline Th & 0.9 & 0.6 & 0.4 & $<.1$ & 1.85 & $<0.5$ & 0.9 & 2.31 & 0.65 & 2.07 & 1.32 \\
\hline $\mathrm{Pb}$ & 1.8 & 2 & 3.4 & 1.2 & $<30$ & $<30$ & $<30$ & $<30$ & $<30$ & $<30$ & $<30$ \\
\hline Sn & $<1$ & $<1$ & $<1$ & $<1$ & $<20$ & $<20$ & $<20$ & $<20$ & $<20$ & $<20$ & $<20$ \\
\hline Sc & 32 & 39 & 44 & 56 & 25.7 & 25.2 & 22.2 & 21.9 & 31 & 33.6 & 23.1 \\
\hline $\mathrm{La}$ & 4.7 & 2.2 & 4.3 & 3.6 & 12.6 & 12.3 & 11.5 & 15.1 & 5.52 & 10.8 & 16 \\
\hline $\mathrm{Ce}$ & 12.2 & 5.9 & 12.9 & 10.7 & 31.4 & 33 & 28.1 & 32.9 & 13.5 & 24.3 & 35.8 \\
\hline $\operatorname{Pr}$ & 1.68 & 0.96 & 2.06 & 1.5 & 4.16 & 4.54 & 3.81 & 4.35 & 1.93 & 3.18 & 4.47 \\
\hline $\mathrm{Nd}$ & 7.3 & 4.7 & 10.7 & 8.3 & 19.2 & 20.3 & 18.1 & 18.3 & 9.33 & 14.3 & 19.8 \\
\hline $\mathrm{Sm}$ & 2.2 & 1.7 & 3.1 & 2.8 & 4.64 & 4.12 & 3.96 & 3.79 & 2.35 & 3.19 & 4.22 \\
\hline $\mathrm{Eu}$ & 0.84 & 0.62 & 1.13 & 1.03 & 1.38 & 1.25 & 1.13 & 1.04 & 0.83 & 1 & 1.19 \\
\hline $\mathrm{Gd}$ & 2.75 & 2.11 & 3.61 & 4.17 & 4.98 & 4.29 & 4.52 & 3.73 & 2.61 & 3.35 & 4.54 \\
\hline $\mathrm{Tb}$ & 0.58 & 0.47 & 0.67 & 0.86 & 0.78 & 0.57 & 0.65 & 0.51 & 0.43 & 0.46 & 0.76 \\
\hline Dy & 3.84 & 3.21 & 4.44 & 5.99 & 4.38 & 3.27 & 3.35 & 3.27 & 2.39 & 2.59 & 4.62 \\
\hline Ho & 0.84 & 0.69 & 0.84 & 1.36 & 0.88 & 0.68 & 0.68 & 0.56 & 0.48 & 0.54 & 0.91 \\
\hline Er & 2.45 & 1.8 & 2.3 & 4.04 & 2.22 & 1.67 & 1.78 & 1.46 & 1.33 & 1.27 & 2.76 \\
\hline $\mathrm{Tm}$ & 0.36 & 0.29 & 0.34 & 0.61 & 0.31 & 0.24 & 0.26 & 0.22 & 0.2 & 0.22 & 0.38 \\
\hline $\mathrm{Yb}$ & 2.45 & 2 & 2.37 & 4.21 & 2.18 & 1.43 & 1.76 & 1.44 & 1.32 & 1.29 & 2.65 \\
\hline $\mathrm{Lu}$ & 0.4 & 0.27 & 0.29 & 0.65 & 0.3 & 0.21 & 0.24 & 0.21 & 0.2 & 0.19 & 0.39 \\
\hline
\end{tabular}

$<$ value below the given detection limit 


\section{Major elements}

The $\mathrm{SiO}_{2}$ contents of the samples vary between 45 and $61 \%$, which classify them to range from basalts to andesites. From the TAS diagram (Fig. 2) and from the major elements vs $\mathrm{MgO}$ plots (Fig. 3), it is evident that in average the Vahto group tends to show higher contents of alkalis and silica compared to the Pargas and Turku groups. The Pargas and Turku groups also show, excluding few differing samples, higher contents of $\mathrm{CaO}$ and $\mathrm{P}_{2} \mathrm{O}_{5}$. Other major elements show no clear grouping (Fig. 3). The analysed samples plot quite well within the igneous spectrum of Hughes (1973), indicating a rather low alkali alteration. The igneous spectrum diagram is shown in Westerlund (2005).

\section{Trace elements}

When the data are plotted on the $\mathrm{Zr} / \mathrm{Ti}$ vs $\mathrm{Nb} / \mathrm{Y}$ diagram (Fig. 4) it is evident that more data plot in the basalt field, including all the Pargas and Turku data, than using the TAS diagram in Fig. 2.

Other trace element data are presented in form of chondrite-normalised rare earth element (REE) diagrams and mid-ocean ridge basalt (MORB) normalised multielement diagrams that also include major elements $\mathrm{K}$ and Ti. The data are presented separately for each group below.

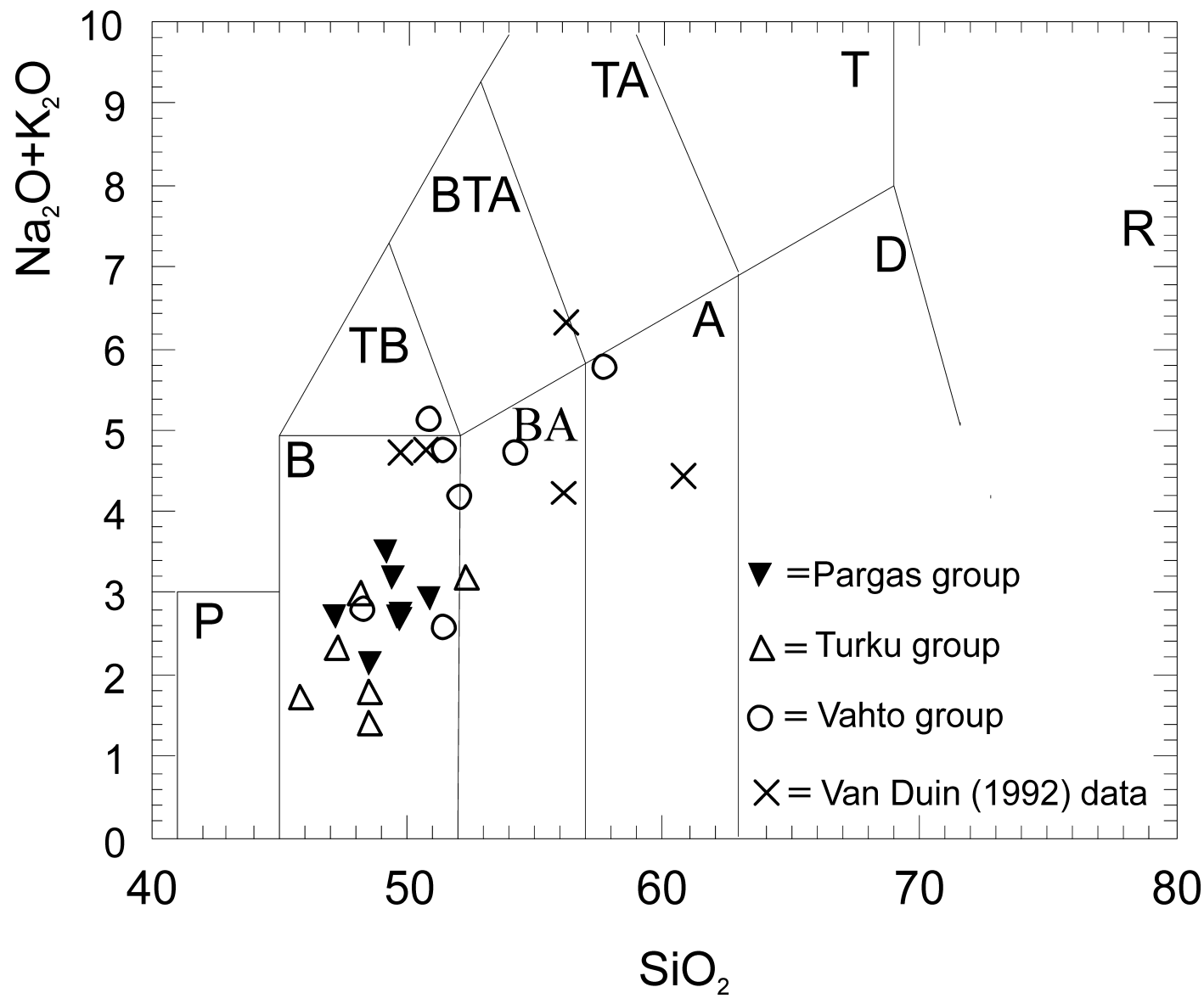

Fig. 2. Total alkali vs silica (TAS) diagram. Fields according to Le Maitre et al. (1989). 


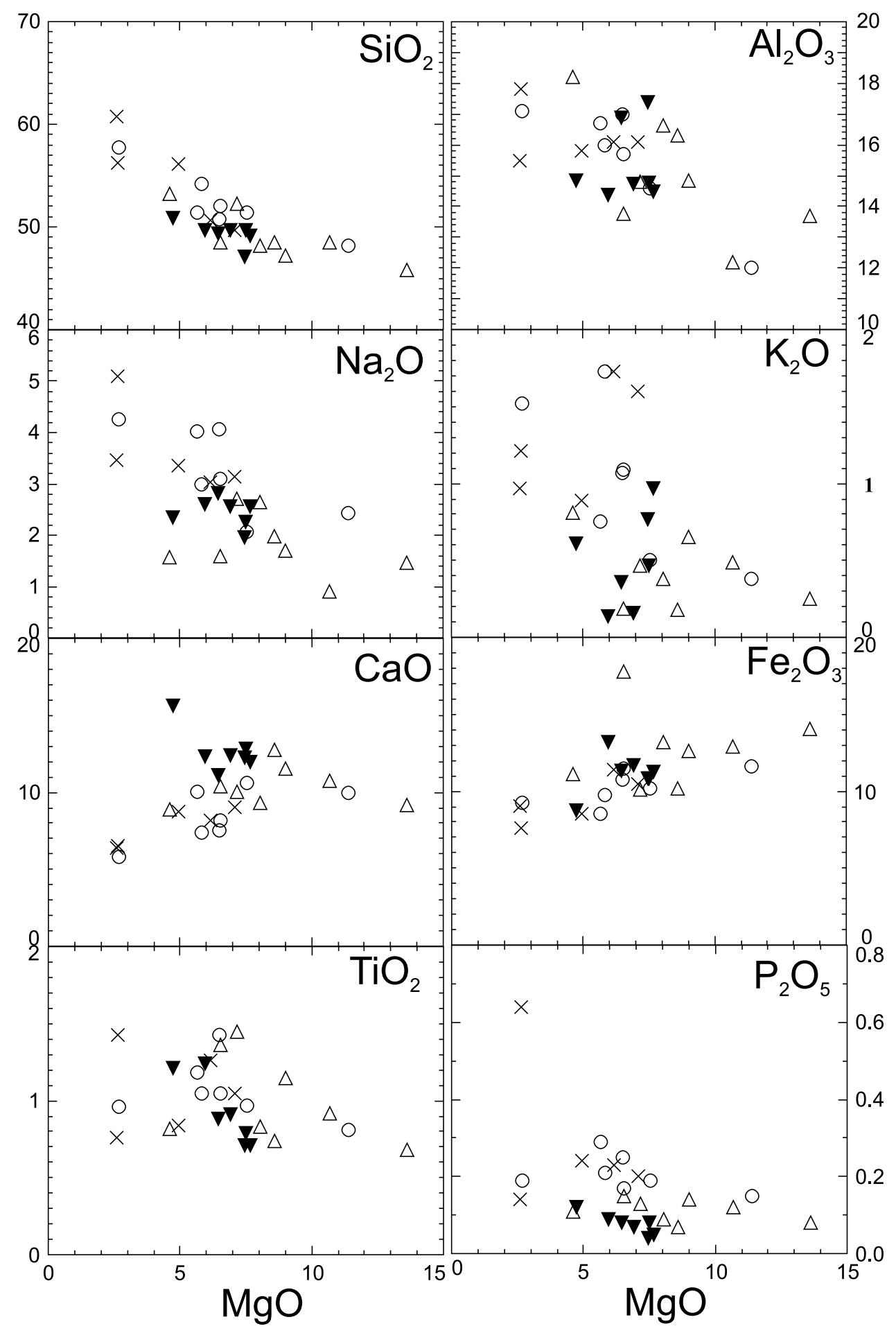

Fig. 3. Major element vs MgO diagrams. Symbols as in Fig. 2. 


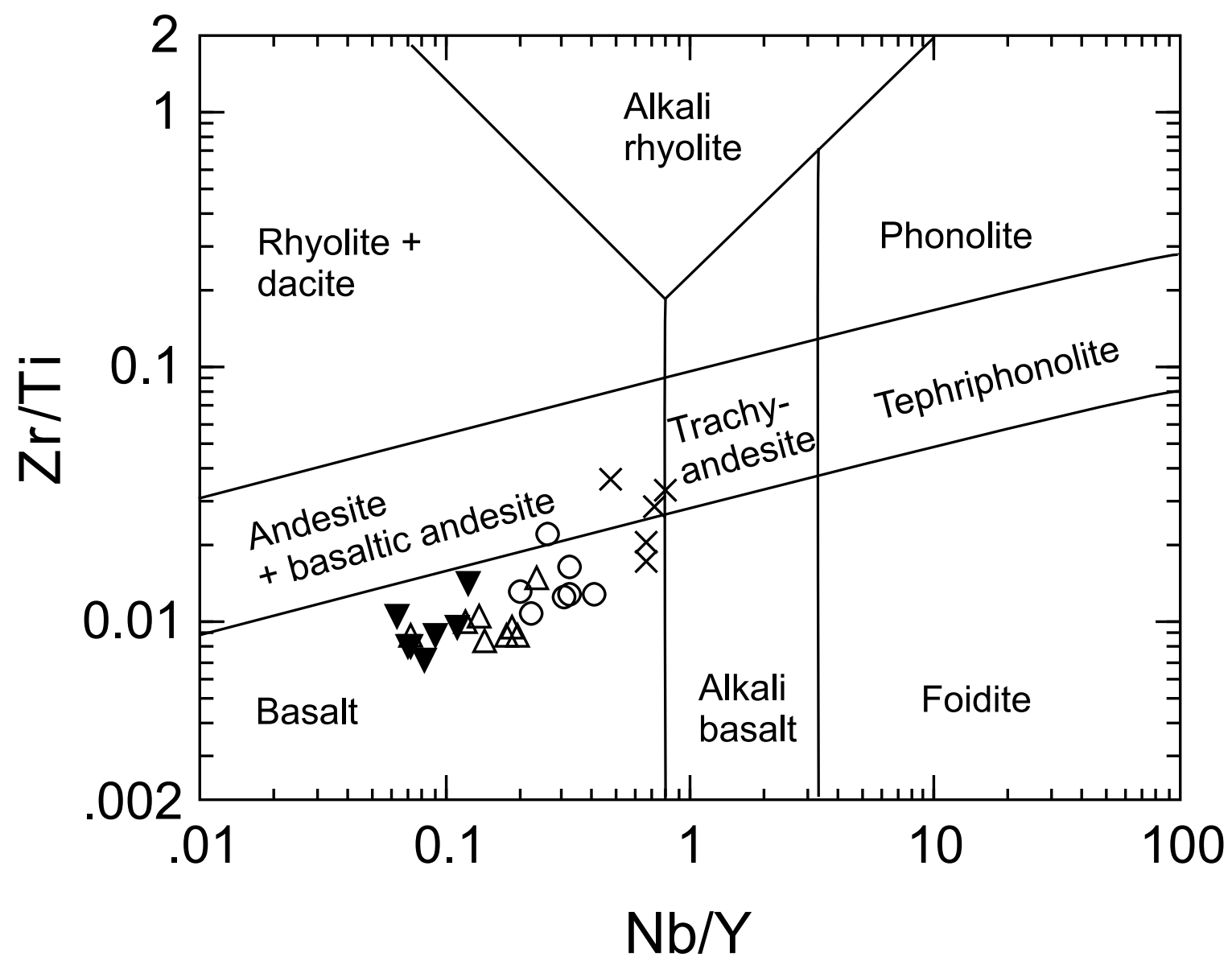

Fig. 4. $\mathrm{Zr} / \mathrm{Ti}$ vs $\mathrm{Nb} / \mathrm{Y}$ diagram after Pierce (1996). Symbols as in Fig. 2.

\section{I. Pargas group}

All the samples from this group come from the same volcanic unit underlying the marble horizon. Therefore, they are assumed to belong to the same magmatic phase.

The REE contents of the mafic rocks generally show quite a flat pattern, in average roughly twelve times enriched relative to chondrite (Fig. 5a). Eu shows both small negative and positive anomalies, possibly correlating with the amount of plagioclase in the samples. The sample ABO5-GJW-03 differs from other samples in showing more enriched REEs, LREEs in particular. We interpret that this is caused by secondary processes because the sample was tak- en from highly strained and partly migmatised outcrop. Another sample (119-MAV-02) shows slightly depleted LREEs relative to other samples.

The multielement diagram (Fig. 5b) shows that, in general, the Pargas volcanic rocks are variably enriched in LIL-elements and slightly depleted in most HFS-elements compared to MORB. Rb, in particular, shows a wide scatter. Most Th and all Ce abundances are enriched compared to neighbouring elements which, consequently, causes small $\mathrm{Ta}-\mathrm{Nb}$ troughs. As in the REE diagram, the sample ABO5-GJW-03 differs and is relatively rich in most elements. 

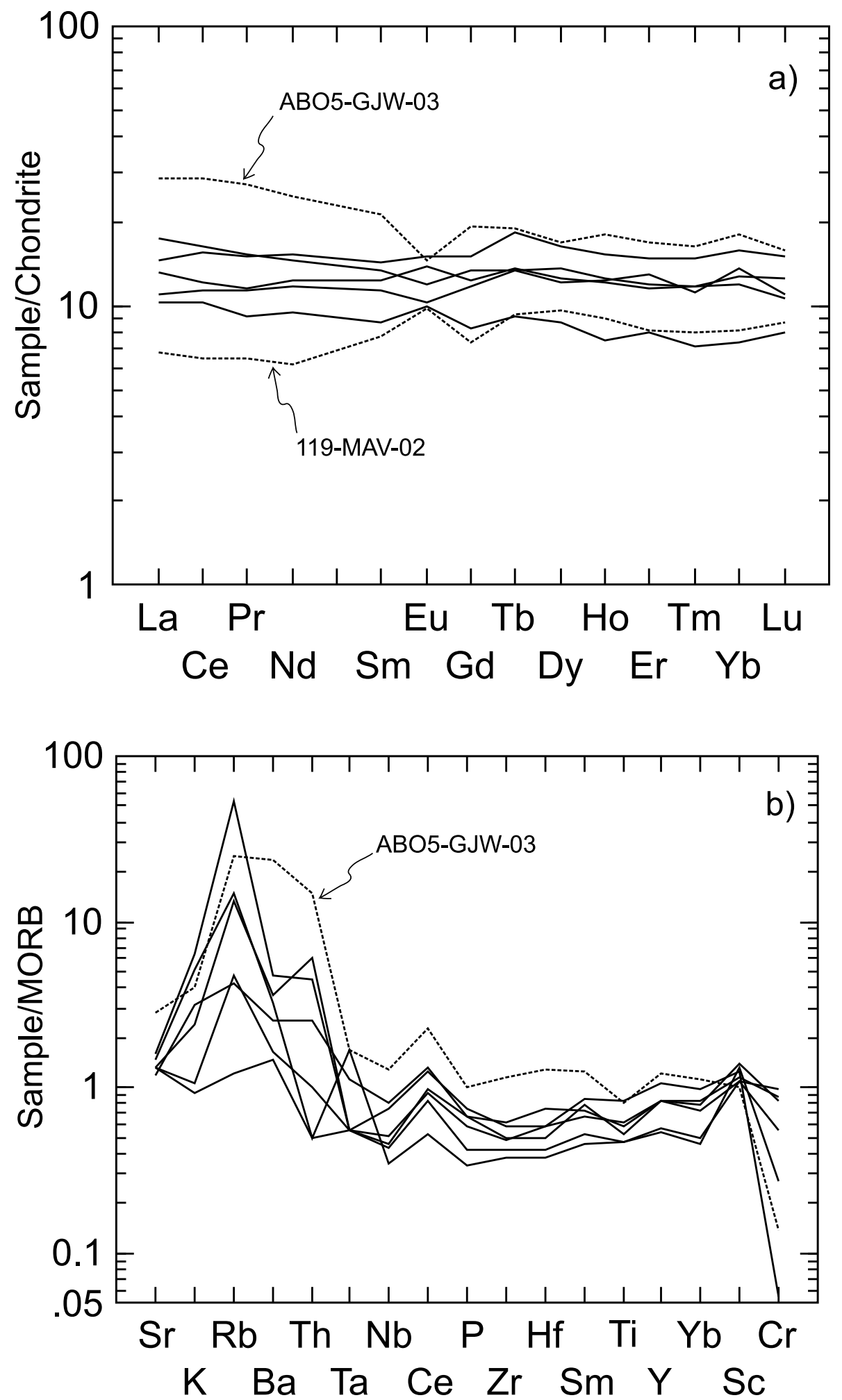

Fig. 5. Data from the Pargas group volcanic rocks. Samples referred to in the text are by dashed lines and indicated by arrows. a) Chondrite normalised REE diagram (normalisation after Boynton, 1984). b) N-MORB normalised multielement diagram (normalisation after Pearce, 1982). 


\subsection{Turku group}

In this group the samples come from quite thin volcanic layers widely scattered across the study area (see Fig. 1 for sample locations). Therefore, their mutual field relations are not that clear. In spite of that, the data show good coherence.

The REE patterns of the samples (Fig. 6a) show a slight scatter with both gentle negative and gen- tle positive slopes (samples 118-MAV-02 and 347.1MJV-03). Sample ABO8-GJW-03 show clear LREE enrichment and sample 118-MAV-02 LREE depletion relative to other samples.

The multielement diagram (Fig. 6b) shows a slight LIL-element enrichment except sample ABO8-GJW03 that shows a stronger enrichment, in accordance
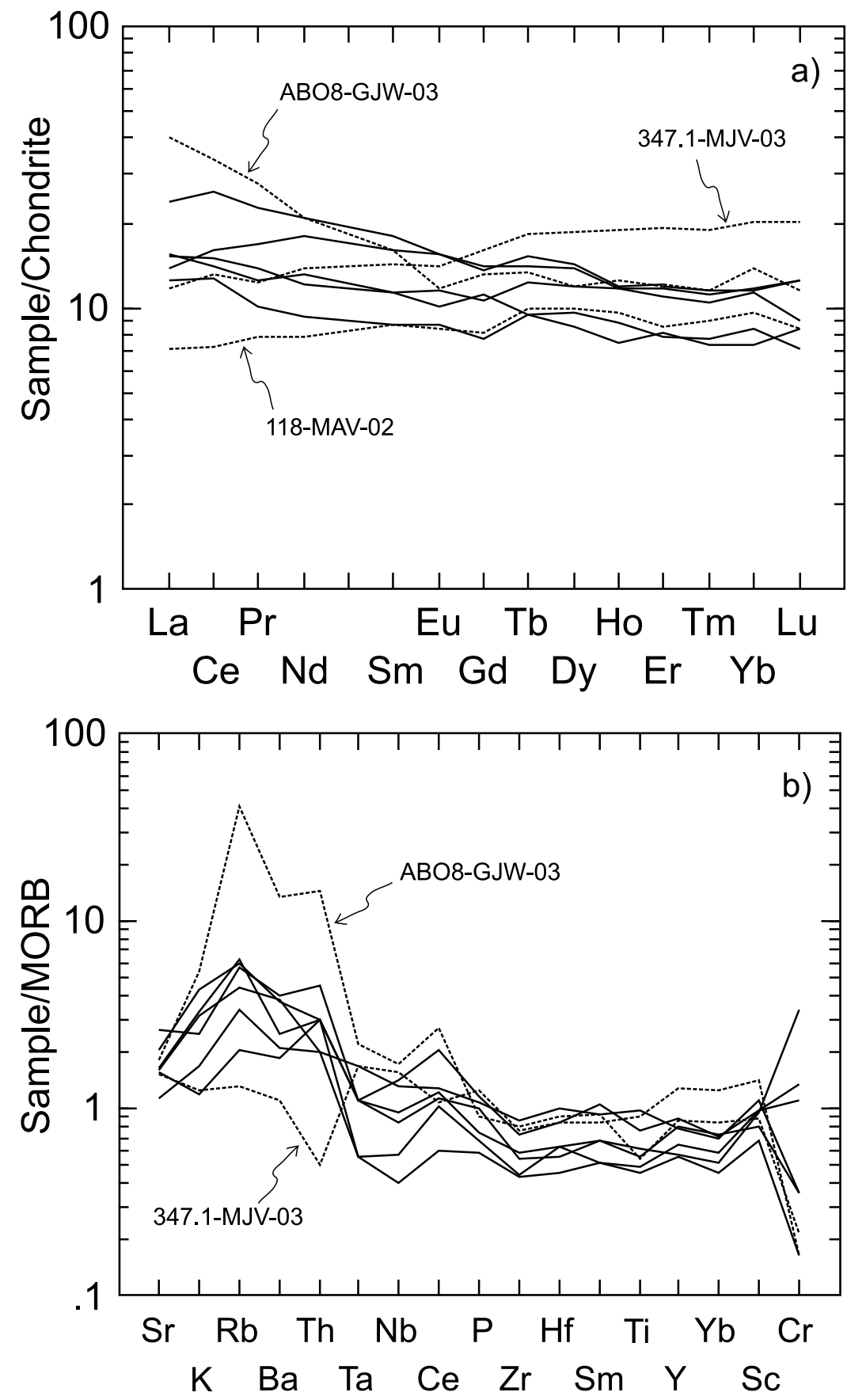

Fig. 6. Data from the Turku group volcanic rocks. Samples referred to in the text are by dashed lines and indicated by arrows. a) Chondrite normalised REE diagram (normalisation after Boynton, 1984). b) N-MORB normalised multielement diagram (normalisation after Pearce, 1982). 
with the LREE enrichment of the same sample. HFSelement contents are, in average, slightly depleted relative to MORB but the patterns are very similar to it. Ce shows slight enrichments, and $\mathrm{Ta}-\mathrm{Nb}$ shows weak negative anomalies. Sample 347.1-MJV-03 differs as it shows practically no LILE enrichment and a negative Th anomaly. Except for the Th trough, the pattern is close to that of MORB.

\subsection{Vahto group}

Samples from the Vahto group are characterised, compared to the samples from the other two groups, by higher LREE/HREE ratios. This is visible as negative slopes on REE patterns (Fig. 7a). Sample 121MJV-03, which is the most mafic sample within the Vahto group, shows the least pronounced enrich-
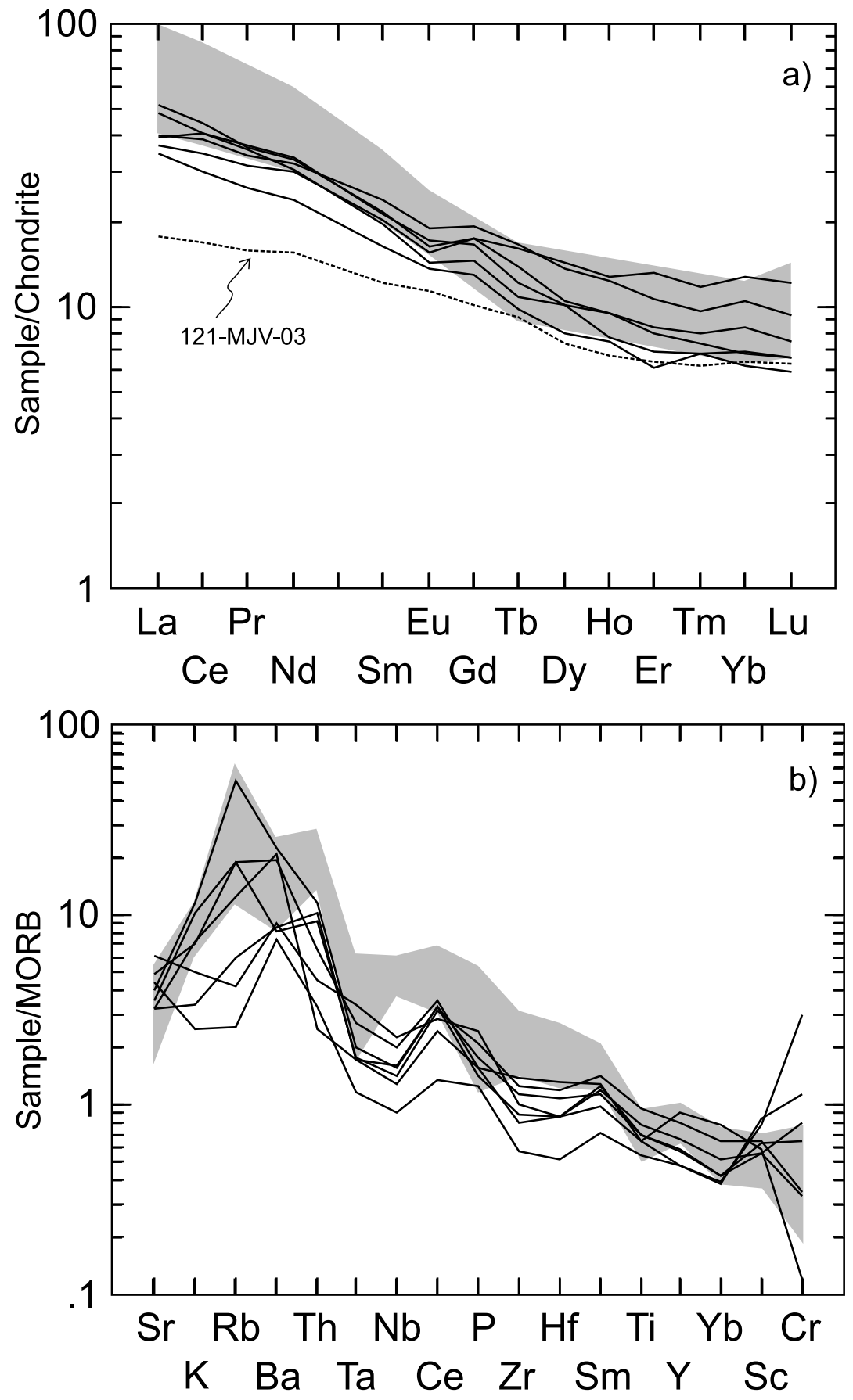

Fig. 7. Data from the Vahto group volcanic rocks. The grey shades in the figures show the compositional range of data from van Duin (1992). Sample referred to in the text are by dashed line and indicated by arrow. a) Chondrite normalised REE diagram. (normalisation after Boynton, 1984) b) N-MORM normalised multielement diagram. (normalisation after Pearce, 1982). 
ment. Van Duin's (1992) data display higher LREE concentrations.

In the multielement diagram (Fig. 7b), samples are characterized by moderate LILE/HFSE ratios. This is shown as variable enrichment of $\mathrm{K}, \mathrm{Rb}, \mathrm{Ba}, \mathrm{Th}, \mathrm{Ce}$ and $\mathrm{P}$ while the Ta, Nb, Zr, Hf, Sm, Ti, Y and $\mathrm{Yb}$ values successively decrease in order of incompatibility. $\mathrm{Rb}$ shows the widest scatter. The most incompatible elements, $\mathrm{Ti}, \mathrm{Y}$ and $\mathrm{Yb}$ are the most depleted ones, which plot below N-MORB compositions. Ta and $\mathrm{Nb}$ show negative anomalies. In average, the HFSE patterns form a negative slope.

\section{Discussion and conclusions}

The geochemical data of the Pargas and the Turku groups show many similarities. Both display quite flat REE patterns and more or less similar patterns in multielement diagrams (Figs 5 and 6), namely LILE enrichment and HFSE patterns slightly below
MORB but nearly parallel to it. Although many features resemble MORBs, slight enrichments in LILE, $\mathrm{Ce}$ and $\mathrm{P}$ and weak $\mathrm{Ta}-\mathrm{Nb}$ troughs are more common among subduction-related arc rocks. Th abundances vary considerably causing high $\mathrm{Th} / \mathrm{Nb}$ ratios in many samples. These features indicate either subduction signature or crustal contamination (Stern et al., 1995b; Pearce, 1996). Scatter in Th contents is also manifested in poor discrimination using Th-based diagrams and data plot in MORB and ARC fields (e.g. in $\mathrm{Zr}-\mathrm{Nb}-\mathrm{Th}$ diagram, not shown). The samples show increasing $\mathrm{Ti}$ with increasing $\mathrm{Zr}$ and plot in MORB field in the Ti vs $\mathrm{Zr}$ diagram (Fig. 8). In this respect the data resemble that of the Vestlax formation in Kemiö (Lindroos \& Ehlers, 1994) and the Salittu formation in Orijärvi (Väisänen \& Mänttäri, 2002) as is also shown in the recent review and plots by Kähkönen (2005). Since the data show features both from MORBs and VABs (volcanic arc basalts), we call these groups as transitional between MORBs

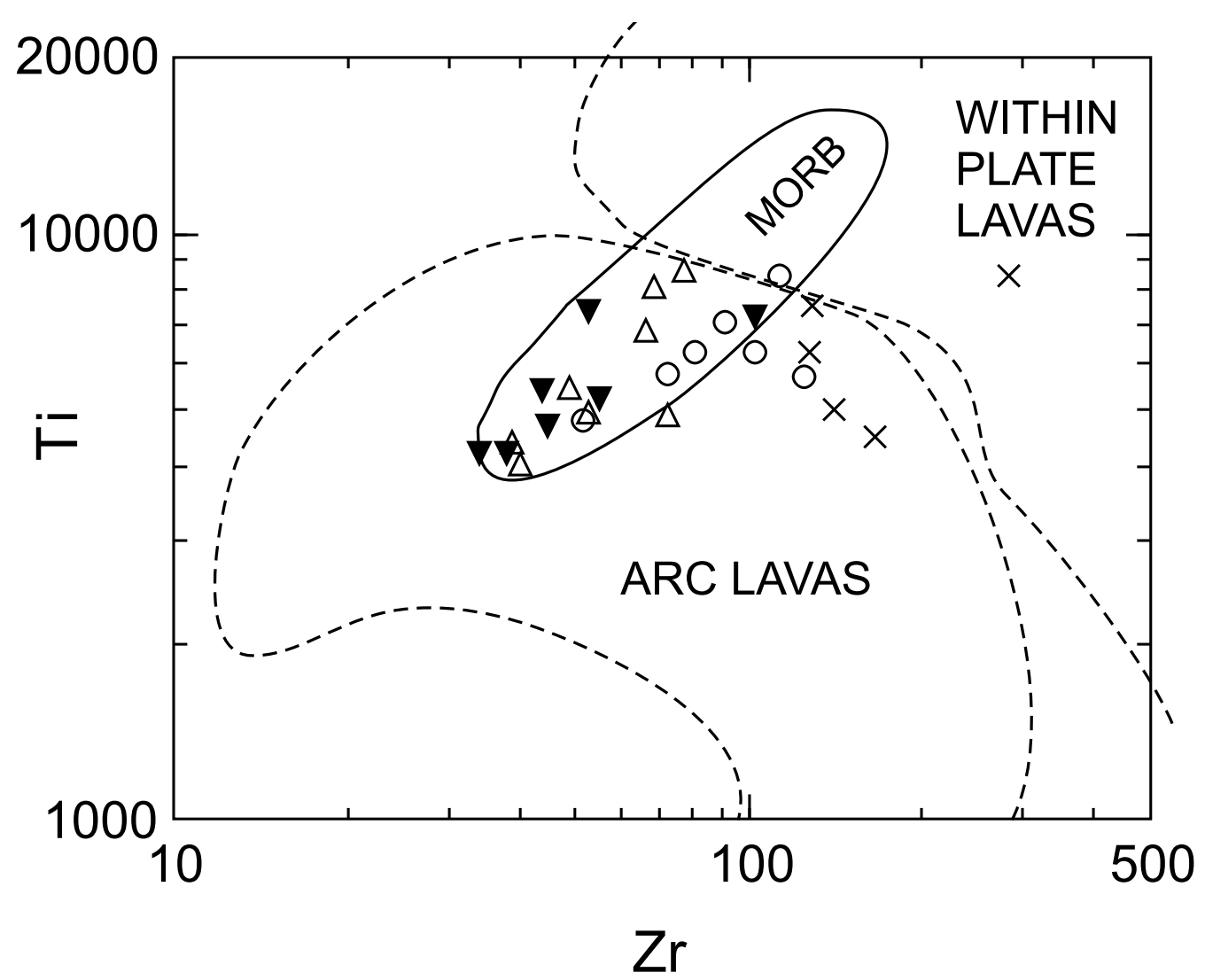

Fig. 8. Ti vs Zr diagram after Pearce (1982). Symbols as in Fig. 2. 
and VABs as classified by Pearce (1996). Transitional data are common among marginal basins, but to infer the basin type requires other independent geological evidences (Pearce, 1996).

Three main alternatives are possible to explain the mafic volcanism erupted in sedimentary basin: 1) Mafic rocks were erupted in fore-arc setting. This scenario is not favoured as fore-arcs are supposed to contain boninitic magmas (e.g. Stern et al., 1995a) which are not found here. 2) Mafic rocks were erupted through an older rifted (attenuated) crust (Ehlers et al., 1986; Lahtinen et al., 2005). This is fully possible scenario, since the sediments contain both Archaean and older Palaeoproterozoic detrital zircons (Väisänen et al., 2002). 3) Mafic rocks were erupted in back-arc or intra-arc setting during rifting of arc of roughly the same age (Väisänen \& Mänttäri, 2002). This interpretation fits with existing age data of the crust in southern Finland and connects the Turku area to the Kemiö area and the Toija and Salittu formations in the Orijärvi area. We prefer this interpretation.
The geochemical data from the Vahto group differ from that of the Pargas and Turku groups. The enriched LREEs and LILEs, positive anomalies of Ce, $\mathrm{P}$ and $\mathrm{Sm}$ combined with $\mathrm{Ta}-\mathrm{Nb}$ troughs all point to subduction signature. In the $\mathrm{Ti}$ vs $\mathrm{Zr}$ diagram (Fig. 8) the samples plot both in the MORB and in the ARC fields with no apparent $\mathrm{Ti}-\mathrm{Zr}$ correlation. The data from the Häme belt (Hakkarainen (1994) and Lahtinen (1996), plotted in Kähkönen (2005), show a similar scatter. The REE and multielement diagrams in this study and from the Häme belt (op. cit) also show striking similarities. Therefore, as previously inferred from its geographically close position and especially from geological maps (e.g. Korsman et al., 1997), it is obvious also on geochemical grounds that the volcanic rocks within the Vahto group belong to the Häme belt.

Although the data of the Vahto group show an arc signature, the precise type of arc is less clear. Typical (oceanic) island arc basalts generally have normalised HFSE contents below the MORB-level which is

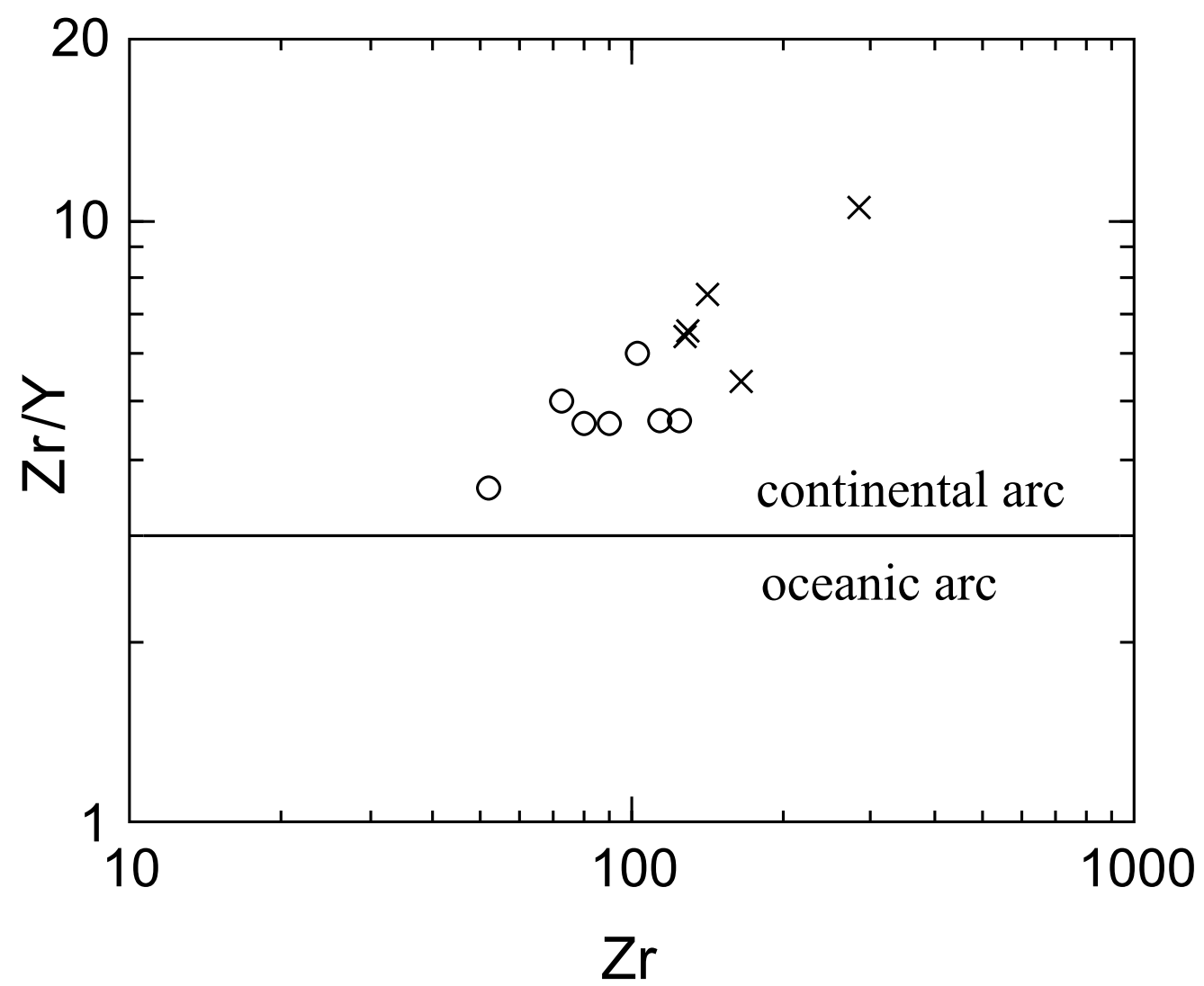

Fig. 9. $\mathrm{Zr} / \mathrm{Y}$ vs $\mathrm{Zr}$ diagram, data from the Vahto group. Boundary line between continental and oceanic arcs after Pearce (1983). Symbols as in Fig. 2. 
not the case in these samples. The multielement diagram in Fig. $7 \mathrm{~b}$ further shows that the average normalized contents of $\mathrm{Ta}-\mathrm{Nb}>\mathrm{Zr}-\mathrm{Hf}>\mathrm{Y}-\mathrm{Yb}$ are combined with positive anomalies of $\mathrm{Ce}, \mathrm{P}$ and $\mathrm{Sm}$. According to Pearce (1983), these features indicate both subduction and within plate components typically found among continental volcanic arcs (i.e. active continental margins). In the $\mathrm{Zr} / \mathrm{Y}$ vs $\mathrm{Zr}$ diagram the data from the Vahto group plot within the continental arc field (Fig. 9).

Pursuing the idea of the continental volcanic arc, a problem arises about the nature of the continent because at the present erosion level no older continent is known to exist. Detrital zircon data (Claesson et al., 1993) and isotope data have, however, brought the ideas of a hidden older continent beneath the present crust (Lahtinen \& Huhma, 1997). Recently, this enigmatic hidden crust was named as the Bergslagen microcontinent, but it is inferred to be situated below the Uusimaa belt, not the Häme belt (Lahtinen et al., 2005).

In conclusion, our geochemical data on the mafic and intermediate volcanic rocks from the Turku area show that compositions of the rocks fall in two main classes. The mafic volcanic units and intercalations within the sedimentary mica gneisses (the Pargas and Turku groups) show MORB and transitional MORB/VAB geochemical features. We interpret that they were formed in an extensional, preferably in back-arc or intra-arc setting. The rocks from the Vahto group are subduction-related and we interpret that they were formed at a continental volcanic arc.

\section{Acknowledgements}

This study was mainly funded by GTK through mapping of the Mynämäki map sheet. Additional funding was obtained from the Academy of Finland (project 117311) and the Turku University Foundation. Professor Carl Ehlers and Doctor Pekka Sipilä are thanked for their interests to the topic and discussions in the field. Docents Yrjö Kähkönen, Mikko Nironen and Petri Peltonen reviewed the manuscript and suggested numerous improvements.

\section{References}

Boynton, W.W., 1984. Cosmochemistry of the rare earth elements: meteorite studies. In: P. Henderson (ed.), Rare Earth Element Geochemistry. Elsevier, Amsterdam, 63114.

Claesson, S., Huhma, H., Kinny, P.D. \& Williams, I.S., 1993. Svecofennian detrital zircon ages - implications for the Precambrian evolution of the Baltic Shield. Precambrian Research 64, 109-130.

Ehlers, C., Lindroos, A. \& Selonen, O., 1993. The late Svecofennian granite-migmatite zone of southern Finland a belt of transpressive deformation and granite emplacement. Precambrian Research 64, 295-309.

Ehlers, C., Lindroos, A. \& Jaanus-Järkkälä, M., 1986. Stratigraphy and geochemistry in the Proterozoic mafic volcanic rocks of the Nagu-Korpo area, SW Finland. Precambrian Research 32, 297-315.

Ehlers, C., Skiöld, T. \& Vaasjoki, M., 2004. Timing of Svecofennian crustal growth and collisional tectonics in Aland, SW Finland. Bulletin of the Geological Society of Finland 76, 63-91.

Hakkarainen, G., 1994. Geology and geochemistry of the Hämeenlinna-Somero volcanic belt, southwestern Finland: A Paleoproterozoic island arc. Geological Survey of Finland, Special Paper 19, 85-100.

Hughes, C.J., 1973. Spilites, keratophyres and igneous spectrum. Geological Magazine 109, 513-527.

Kähkönen, Y., 2005. Svecofennian supracrustal rocks. In: Lehtinen, M., Nurmi, P. A. \& Rämö, O. T. (eds.) Precambrian Geology of Finland - Key to the evolution of the Fennoscandian Shield. Developments in Precambrian Geology 14. Elsevier B.V., Amsterdam, pp. 343-405.

Korsman, K., Koistinen, T., Kohonen, J., Wennerström, M., Ekdahl, E., Honkamo, M., Idman, H. \& Pekkala, Y., (eds.) 1997. Suomen kallioperäkartta/Bedrock map of Finland 1:1 000 000, Geological Survey of Finland, Espoo.

Lahtinen, R., 1996. Geochemistry of Palaeoproterozoic supracrustal and plutonic rocks in the Tampere-Hämeenlinna area, southern Finland. Geological Survey of Finland, Bulletin 389, 113 p.

Lahtinen, R. \& Huhma, H., 1997. Isotopic and geochemical constraints on the evolution of the 1.93-1.79 Ga Svecofennian crust and mantle in Finland. Precambrian Research 82, 13-34.

Lahtinen, R., Korja, A. \& Nironen, M., 2005. Paleoproterozoic tectonic evolution. In: Lehtinen, M., Nurmi, P. A. \& Rämö, O. T. (eds.) Precambrian geology of Finland Key to the evolution of the Fennoscandian Shield. Developments in Precambrian Geology 14. Elsevier B.V., Amsterdam, pp. 481-531.

Le Maitre, R.W., (ed.) 1989. A classification of igneous rocks and glossary of terms. Blackwell, Oxford, 193 p.

Lindberg, B., Ehlers, C. \& Edén, P., 1994. Turku. Geological map of Finland 1:100 000, pre-Quaternary rocks, sheet 1043, Geological Survey of Finland. 
Lindroos, A. \& Ehlers, C., 1994. Emplacement, deformation and geochemistry of bimodal volcanics in Vestlax, SW Finland. Geological Survey of Finland, Special Paper 19, 173-184.

Macdonald R., Hawkesworth, C.J. \& Heath, E., 2000. The Lesser Antilles volcanic chain: a study in arc magmatism. Earth-Science Reviews 49, 1-76.

Nironen, M., 1999. Structural and magmatic evolution in the Loimaa area, southwestern Finland. Bulletin of the Geological Society of Finland 71, 57-71.

Nironen, M., 2005. Proterozoic orogenic granitoid rocks. In: Lehtinen, M., Nurmi, P. A. \& Rämö, O. T. (eds.) Precambrian geology of Finland - Key to the evolution of the Fennoscandian Shield. Developments in Precambrian Geology 14. Elsevier B.V., Amsterdam, 443-479.

Pearce, J.A., 1982. Trace element characteristics of lavas from destructive plate margins. In: R.S.Thorpe (ed.) Andesites, Orogenic Andesites and Related Rocks. Wiley, Chichester, pp. 525-548.

Pearce, J.A., 1983. Role of subcontinental lithosphere in magma genesis at active continental margins. In: Hawkesworth, C.J., Norry, M.J. (ed.). Continental basalts and mantle xenoliths. Nantwich, Shiva, pp. 230-249.

Pearce, J.A., 1996. A user's guide to basalt discrimination diagrams. In: Wyman, D.A. (ed.) Trace element geochemistry of volcanic rocks: applications for massive sulfide exploration. Geological Association of Canada, Short Course Notes 12, 79-113.

Rämö, O. T. \& Haapala, I., 2005. Rapakivi granites. In: Lehtinen, M., Nurmi, P. A. \& Rämö, O. T. (eds.) Precambrian geology of Finland - Key to the evolution of the Fennoscandian Shield. Developments in Precambrian Geology 14. Elsevier B.V., Amsterdam, 533-562.

Rämö, O.T., Vaasjoki, M., Mänttäri, I., Elliott, B.A. \& Nironen, M., 2001. Petrogenesis of the post-kinematic magmatism of the Central Finland Granitoid Complex I: radiogenic isotope constraints and implications for crustal evolution. Journal of Petrology 42, 1971-1993.

Reinikainen, J., 2001. Petrogenesis of paleoproterozoic marbles in the Svecofennian domain, Finland. Geological Survey of Finland, Report of Investigations 154, 84 p.

Skyttä, P., Käpyaho, A. \& Mänttäri, I., 2005. Supracrustal rocks in the Kuovila area, southern Finland: structural evolution, geochemical characteristics and the age of volcanism. Bulletin of the Geological Society of Finland 77, 129-150.

Stern, R.A., Syme, E.C., Bailes, A.H. \& Lucas, S.B., 1995a. Paleoproterozoic (1.90-1.86 Ga) arc volcanism in the Flin Flon Belt, Trans-Hudson orogen, Canada. Contributions to Mineralogy and Petrology 119, 117-141.

Stern, R.A., Syme, E.C. \& Lucas, S.B., 1995b. Geochemistry of 1.9 Ga MORB- and OIB-like basalts from Amisk collage, Flin Flon belt, Canada: Evidence for an intraoceanic origin. Geochimica et Cosmochimica Acta 59, 3131-3154.
Vaasjoki, M.,1994. Valijärven hapan vulkaniitti: minimi Hämeen liuskejakson iäksi. Summary: Radiometric age of a meta-andesite at Valijärvi, Häme schist zone, southern Finland. Geologi 46, 91-92.

Väisänen, M., 2007. Mynämäki. Geological map of Finland. 1:100 000, pre-Quaternary rocks, sheet 1044. Geological Survey of Finland.

Väisänen, M. \& Hölttä, P., 1999. Structural and metamorphic evolution of the Turku migmatite complex, southwestern Finland. Bulletin of the Geological Society of Finland 71, 177-218.

Väisänen, M. \& Mänttäri, I., 2002. 1.90-1.88 Ga arc and back-arc basin in the Orijärvi area, SW Finland. Bulletin of the Geological Society of Finland 74, 185-214.

Väisänen, M., Mänttäri, I. \& Hölttä, P., 2002. Svecofennian magmatic and metamorphic evolution in southwestern Finland as revealed by U-Pb zircon SIMS geochronology. Precambrian Research 116, 111-127.

Van Duin, J.A., 1992. The Turku Granulite Area, SW Finland: a fluid-absent Svecofennian granulite occurrence. PhD Thesis, Vrije Universiteit, Amsterdam, Holland, $234 \mathrm{p}$.

Westerlund, G.J., 2005. Den geokemiska sammansättningen och petrogenetiska aspekter på mafiska vulkaniter i Åboområdet. M.Sc. Thesis, Åbo Akademi University, 69 p. 